\title{
The Analysis of Quality of Health Services Effect against Patient Satisfaction Patients at Royal Prima Medan Hospital
}

\author{
Delpini Simanjorang*, Riyani Susan Bt Hasan**, Mangatas Silaen***, Ermi Girsang**** \\ * M Author Correspondence: eirene.manjo@gmail.com \\ * Master Program in Public Health, Faculty of Public Health, Universitas Prima Indonesia \\ **Microbiology Faculty of Medicine, Universitas Prima Indonesia Medan \\ ***Obstetrics and Gynecology Faculty of Medicine, Universitas Prima Indonesia Medan \\ ****Department of Masters in Public Health, Universitas Prima Indonesia Medan \\ Sekip street, Sikambing No.Simpang, Sei Putih Tim. I, Medan Petisah, Medan City, North Sumatra, 20111
}

\begin{tabular}{l}
\hline I N D E X I N G \\
\hline Keywords: \\
Quality of Health \\
Services; \\
Patient Satisfaction; \\
Outpatient Care;
\end{tabular}

Kata Kunci:

Kualitas Layanan

Kesehatan;

Kepuasan Pasien;

Rawat jalan;

\begin{abstract}
A B S T R AC T
Data on visits of general patients' outpatient Royal Prima Medan Hospital from February to August 2018 showed a decline. One factor that causes a decrease in patient visits is patient dissatisfaction with the hospital. Indicators of patient satisfaction can consist of health insurance consisting of physical evidence, reliability, responsiveness, assurance and certainty and empathy provided by the hospital to its customers. Quantitative research using cross-sectional and the number of respondents' as many as 89 people using accidental sampling technique. Data analysis was done by multiple linear regressions. A significant influence between the qualities of health services is needed at $97.2 \%$ with a significance value of 0,000 for patient satisfaction. The results of this data analysis indicate that patients are satisfied with the health services provided by Royal Prima Medan Hospital. This shows that there are other factors that come out of this study that causes rejection of patient visits. Obtained a significant between the qualities of health services by $97.2 \%$ of patient satisfaction. For this reason, Royal Prima Medan Hospital is expected to be able to maintain and improve the quality of health services that already exist in hospitals, and find and improve other factors that cause a decrease in patient visits at the hospital.
\end{abstract}

\begin{abstract}
Data pada kunjungan pasien rawat jalan umum Rumah Sakit Royal Prima Medan dari Februari hingga Agustus 2018 menunjukkan penurunan. Salah satu faktor yang menyebabkan penurunan kunjungan pasien adalah ketidakpuasan pasien terhadap rumah sakit. Indikator kepuasan pasien dapat terdiri dari asuransi kesehatan yang terdiri dari bukti fisik, keandalan, daya tanggap, jaminan dan kepastian serta empati yang diberikan oleh rumah sakit kepada pelanggannya. Penelitian kuantitatif menggunakan cross-sectional dan jumlah responden sebanyak 89 orang menggunakan teknik accidental sampling. Analisis data dilakukan dengan regresi linier berganda. Pengaruh signifikan antara kualitas layanan kesehatan diperlukan pada 97,2\% dengan nilai signifikansi 0,000 untuk kepuasan pasien. Hasil analisis data ini menunjukkan bahwa pasien puas dengan layanan kesehatan yang diberikan oleh Rumah Sakit Royal Prima Medan. Ini menunjukkan bahwa ada faktor lain yang keluar dari penelitian ini yang menyebabkan penolakan kunjungan pasien. Diperoleh signifikan antara kualitas pelayanan kesehatan sebesar 97,2\% dari kepuasan pasien. Untuk alasan ini, Rumah Sakit Royal Prima Medan diharapkan dapat mempertahankan dan meningkatkan kualitas layanan kesehatan yang sudah ada di rumah sakit, dan menemukan dan meningkatkan faktor-faktor lain yang menyebabkan penurunan kunjungan pasien di rumah sakit.
\end{abstract}

(C) 2019 JMMR. All rights reserved

Article History: Received 2019-Jun-25; Revised 2019-Jul-10; Accepted 2019-Jul-19

\section{INTRODUCTION}

The number of hospitals in Indonesia has continued to increase very rapidly since 2013 , and more than half of the hospitals in Indonesia are privately owned hospitals. ${ }^{1}$ The utilization of the hospital above is, of course, inseparable from community satisfaction with existing hospitals. Service Quality is a very important thing to still be able to maintain the existence of a hospital. ${ }^{-}$
Royal Prima Medan Hospital as one of the private hospitals has experienced many developments starting from the expansion of hospital buildings, providing complete facilities and other facilities and infrastructure in accordance with the hospital's vision. As one of the private hospitals, the Royal Prima Medan Hospital is inseparable from the intense competition with other hospitals. Patients will choose a hospital that has a positive brand image or a 
pleasant past experience. This will have a positive impact on increasing the number of patient visits at the RSU Royal
Prima Medan.

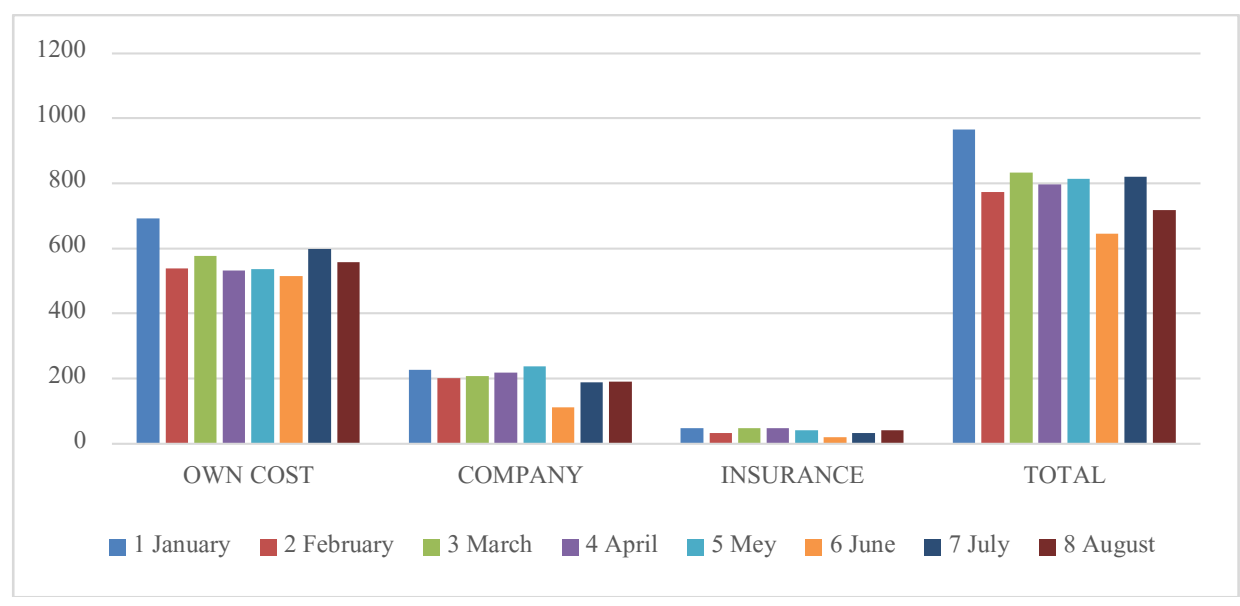

Picture. 1 Number Of Visits Of General Patients In The Road In Prima Medan Royal Hospital 2018

Based on the picture.1 above shows that visits of general patients outpatient at the The Royal Prima Medan Hospital has been unstable and even showed a decline since February - August 2018.

By using the Servqual (Service Quality) Model, it is expected to explain the quality of services in the form of empathy: through the caring attitude shown by health workers, tangibles: officers and hospital building, assurance: guarantee of safety and schedule of doctor visits, reliability: reliability and skills of officers, and responsiveness: the speed of the officer responding to patient complaints. Patient satisfaction as a service user can be assessed from the quality of health services in the hospital, high satisfaction will show the success of the hospital in providing quality health services. The objectives of this study are as follows:

1. To analyze the influence of Tangible on Satisfaction of General Outpatient Patients at RSU. Royal Prima Medan.

2. To analyze the influence of Reliability on Satisfaction of General Patients Outpatient at RSU. Royal Prima Medan.

3. To analyze the effect of Responsiveness on Satisfaction of General Patients Outpatient at RSU. Royal Prima Medan.

4. To analyze the effect of Assurance on Satisfaction of General Patients Outpatient at RSU. Royal Prima Medan.
5. To analyze the influence of Empathy on Satisfaction of General Patients Outpatient at RSU. Royal Prima Medan.

Health services are part of health services that aim to improve health and prevent disease with the goals made by the community because the scope of public health services requires a lot of attention, so the role of the government in public health services is quite large. - $^{-}$

The quality of health services is the level of service perfection in accordance with professional standards and service standards by using available, efficient and effective hospitals or puskesmas resources provided safely and fulfilling the requirements, justice, law and socio-culture by considering limitations and the ability of the government and the consumer community. ${ }^{4}$

Nurmawati divides the quality dimension into 10 (ten) types of competencies such as competency, efficiency, access, human relations, continuity of service, security, comfort, information, and timeliness. While Parasuraman, Zeithaml, and Berry in Bustami quoted by Satrinegara classify dimensions of service quality into five dimensions known as ServQual. ${ }^{-}$The five quality dimensions

1. Tangibles. Tangibles are physical facilities, equipment and supplies, and the appearance of personnel. Waiting rooms, operating rooms, equipment and written materials. Tangibles can be seen in terms of buildings, equipment, service providers uniforms. $\underline{6}$

2. Reliability. Reliability is the ability to provide services that are in accordance with what is expected 
accurately and satisfactorily. The promise was kept in accordance with the schedule, the diagnosis proved to be accurate.

3. Response. Responsiveness is the ability of officers to provide responsive and immediate service. Easy to access, no longer waiting, ready to listen to the complaints of patients.

4. Guarantee. Assurance is the knowledge, ability, freedom and expertise needed by officers to provide services with trust and confidence and freedom from danger, worries and doubts. Doubts, skills, competencies and expertise.

5. Empathy. Empathy is communicating in relationships, good communication, both personal and understanding customer needs. Get to know patients well, remember problems (illnesses, complaints, etc.) beforehand, listeners who are kind and patient.

According to Philip Kotler who quoted Purwoastuti \& Walyani, the notion of satisfaction is the level received by someone who is the result of a comparison of the results or results of products received with expectations with someone. Patient satisfaction from patients arising from health services obtained after the patient compares with what he expected. ${ }^{13}$ Satisfaction or dissatisfaction is feeling happy or disappointed someone who comes from the comparison between his impression of the performance of products / services that are real / actual with the expected product / service performance. ${ }^{-}$

\section{RESEARCH METHOD}

This research is a quantitative research with a crosssectional study which aims to analyze the importance of service to patient satisfaction. The place of this research was carried out in the Outpatient Room of Royal Prima Medan Hospital and was held in September 2018-February 2019. The population in this study was all general patients in the Outpatient Room of Royal Prima Medan Hospital in 2018. The general patients requested in this study were patients with the characteristics of payment of maintenance costs at their own expense, insurance and company. The sample is part of the number and characteristics possessed by the population, carried out by accidental sampling technique that is as many as 89 people. ${ }^{-}$The selection of research samples is based on the following criteria:

1. The inclusion criteria in this study are:
a. Outpatients at least 2 visits.
b. Adult patients $\geq 18$ years (WHO)
c. Patients are able to read and write

d. Patients are able to communicate well.

e. Patients Willing to be Respondents

2. Exclusion criteria were taken or excluded subjects who met the inclusion criteria from the study due to various reasons. The exclusion criteria for this study are:

a. Patients who understand less than 2 days

b. Child patients or patients who cannot read and write

c. Patients who fill the sheet.

\section{RESULT AND DISCUSSION}

Multivariate analysis was conducted to determine the magnitude of the influence between the dependent and independent variables. This multiple linear analysis is used to analyze the influence of the independent variables (tangibles, reliability, responsiveness, assurance, empathy) on the dependent variable (patient satisfaction).

The multiple linear regression equations used in this study are as follows: $\mathrm{Y}=\mathrm{a}+\mathrm{b} 1 \mathrm{X} 1+\mathrm{b} 2 \mathrm{X} 2+\mathrm{b} 3 \mathrm{X} 3+\mathrm{b} 4 \mathrm{X} 4+$ $\mathrm{b} 5 \mathrm{X} 5+\mathrm{e}$

Information:

$\mathrm{Y}=$ Patient Satisfaction $\mathrm{X} 1=$ Tangible

$\mathrm{X} 2=$ Reliability X3 $=$ Responsiveness X4 = Essurance

X5 = Empathy

$\mathrm{a}=$ Constant, b1, b2, b3, b4, b5 = Regression Coefficient, e $=$ error.

\section{Characteristics of Respondents}

Table 1. Frequency Distribution Based on Age Group, Gender, Education and Employment

\begin{tabular}{lll}
\hline Characteristics of Respondents & Frequency & (\%) \\
\hline AGES & 12 & \\
$\leq 30 \quad$ years & 35 & 13,5 \\
$31-50$ years & 42 & 49,5 \\
$\geq 51 \quad$ years & 33 & 37,1 \\
Male & 56 & 62,9 \\
Female & & \\
TYPE OF WORK & 8 & 9 \\
Government employees & 24 & 27 \\
Housewife & 28 & 31,5 \\
Private employees & 19 & 21,3 \\
Entrepreneur & 10 & 11,2 \\
Others & & \\
LAST EDUCATION & 43 & 48,3 \\
High school & 46 & 51,7 \\
College & & \\
\hline
\end{tabular}


Distribution of Frequency Variables in Quality of Health Services

\section{Tangible}

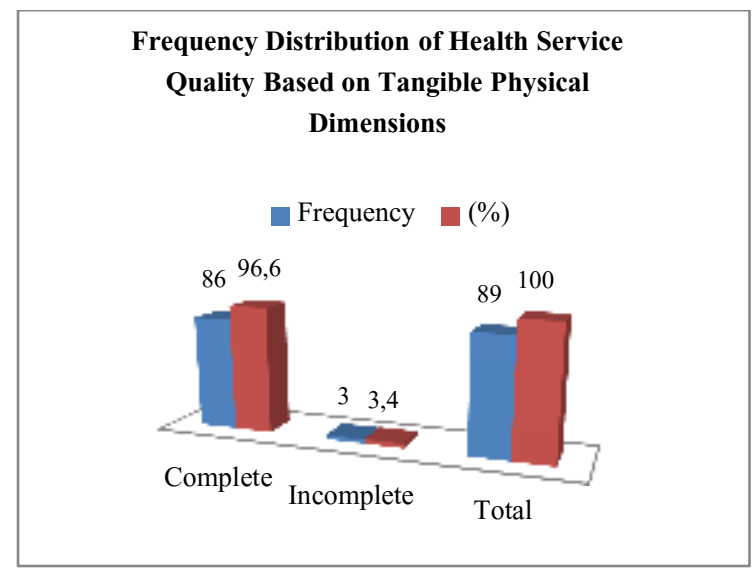

Picture 2. Frequency Distribution of Health Service Quality Based on Tangible Physical Dimensions

From picture 2 above it is known that the Tangible of the Royal Prima Medan Hospital in the majority of respondents stated that there were 86 respondents $(96.6 \%)$ and incomplete minorities as many as 3 respondents (3.4\%).

\section{Reliability}

Table 2. Frequency Distribution of Quality of Health Services Based on the Dimensions of Reliability

\begin{tabular}{lll}
\hline Reliability & Frequency & $\mathbf{( \% )}$ \\
\hline Reliable & 84 & 94,4 \\
Not Reliable & 5 & 5,6 \\
Total & $\mathbf{8 9}$ & $\mathbf{1 0 0}$
\end{tabular}

From table 2 the Reliability of Royal Prima Hospital the majority of respondents said that there were 84 respondents $(94.4 \%)$ and the unreliable minority as many as 5 respondents $(5.6 \%)$.

\section{Responsiveness}

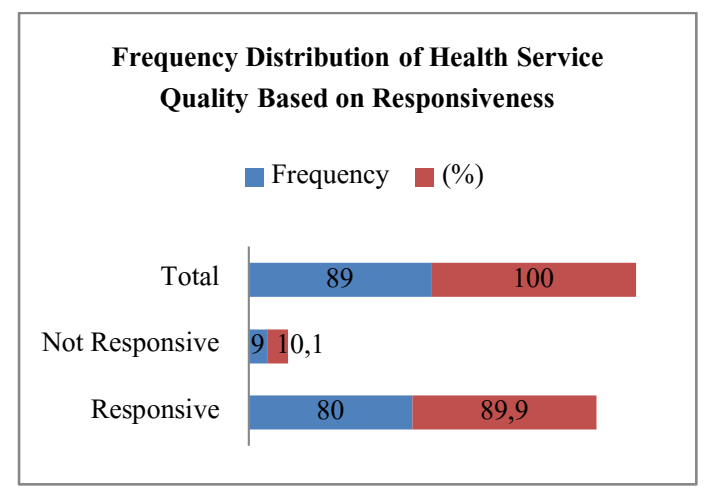

Picture 3. Frequency Distribution of Health Service Quality Based on Responsiveness
From picture 3 above, it is known that the Responsiveness of the Royal Prima General Hospital, the majority of respondents said that there were 80 respondents (89.9\%) and responsive minorities as many as 9 respondents $(10.1 \%)$.

\section{Assurance}

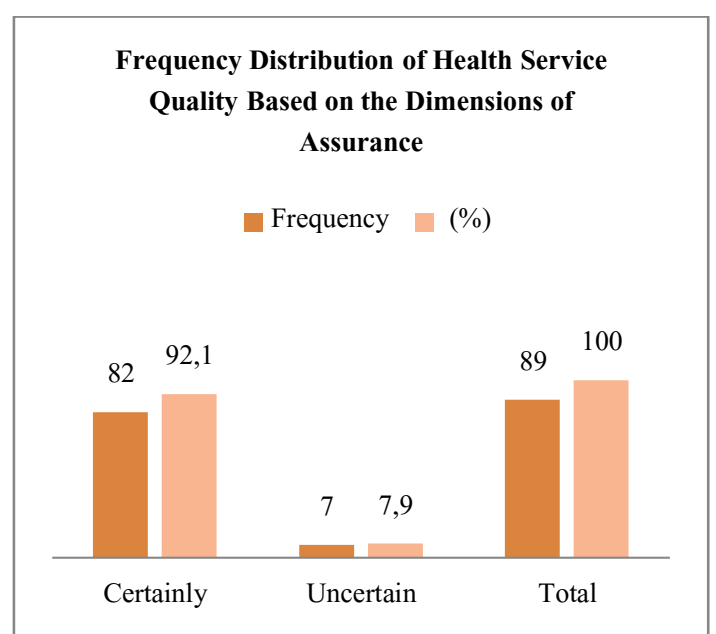

Picture 4. Frequency Distribution of Health Service Quality Based on the Dimensions of Assurance

From picture 4. above, it is known that the Assurance of the Royal Prima General Hospital of the majority of respondents stated that there were as many as 82 respondents $(92.1 \%)$ and the minority stated that there were 7 respondents $(7.9 \%)$.

\section{Empathy}

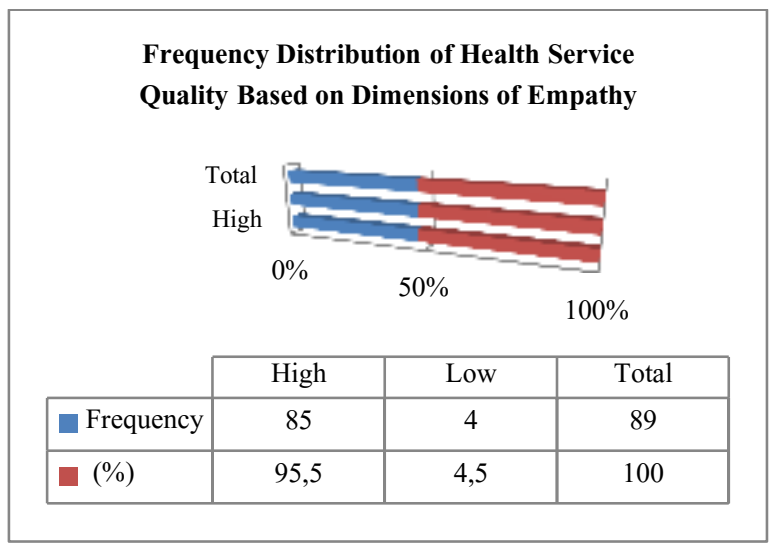

Picture 5. Frequency Distribution of Health Service Quality Based on Dimensions of Empathy

From picture 5 above, it is known that the Empathy of Royal Prima General Hospital, the majority of respondents stated that there were 85 respondents $(95.5 \%)$ and 
minorities stated that there were 4 respondents (4.5\%) who were low.

\section{Variable Frequency Distribution of Patient Satisfaction}

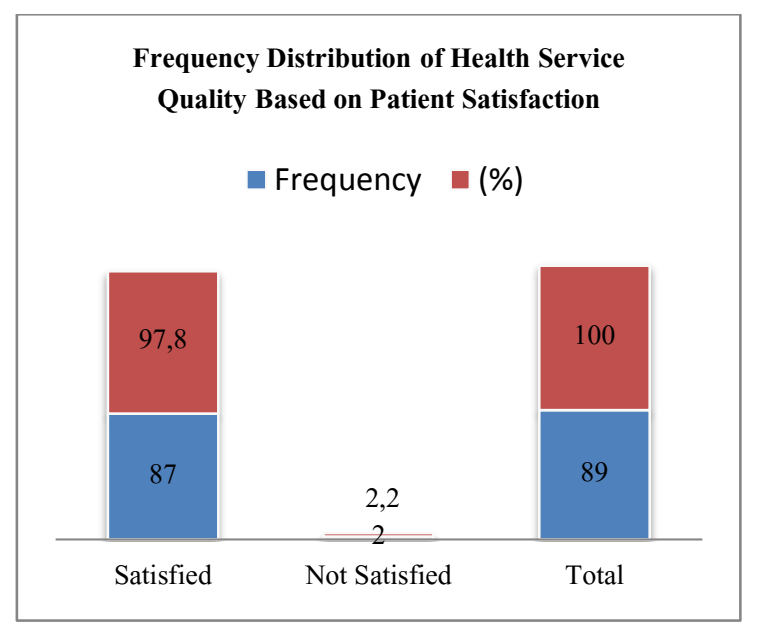

Picture 6. Frequency Distribution of Health Service Quality Based on Patient Satisfaction
From picture 6 above, it is known that the Patient Satisfaction of Royal Prima General Hospital, the majority of respondents stated that they were satisfied as many as 87 respondents (97.8\%) and minorities stated that they were not satisfied as much as 2 respondents $(2.2 \%)$.

\section{Data Analysis Results}

Multivariate analysis is an analysis used to see the most dominant factors influencing service quality variables, namely direct evidence, reliability, responsiveness, assurance and empathy for the dependent variable of patient satisfaction using multiple linear regression tests with a significance level of 0.05 or with a level of trust $95 \%$.

The following are the results of multiple linear regression tests on the Independent Variables of Health Service Quality on the Dependent Variables of General Outpatient Patients Satisfaction in Royal Prima Hospital Medan.

Table 3. Hypothesis Test Results

\begin{tabular}{llllll}
\hline Model & Sum Of & Df & Mean Square & F & Sig. \\
& Squares & & & \\
\hline Regression & 1582,777 & 5 & 316,555 & 605,044 & $0,000^{\mathrm{b}}$ \\
Residual & 43,425 & 83 & 523 & & \\
Total & 1661,910 & 88 & & \\
\hline
\end{tabular}

Based on table 3 above, it is obtained that the significant number is 0,000 . Figures $0,000<0,05$ then Ho is rejected and $\mathrm{Ha}$ is accepted. It is important to consider the quality of service to the satisfaction of general outpatient patients at Royal Prima Hospital Medan. Therefore there is an influence between the Health Service Quality variable (X) and the Patient Satisfaction variable (Y).

Table 4. Results of Multiple Linear Regression Analysis of Service Quality Variables on Variable Satisfaction Levels of General Outpatients in Royal Prima Hospital Medan

\begin{tabular}{lcl}
\hline Variable & Koefisien Regresi & Sig. \\
\hline (Constant) & 5,646 & 0,000 \\
Tangible) & 0,534 & 0,000 \\
Reliability & 0,193 & 0,028 \\
Responsiveness & 0,032 & 0,539 \\
Assurance & 0,140 & 0,031 \\
Empathy & 0,241 & 0,003 \\
\hline
\end{tabular}

Based on table 4, and table 3 above, the regression equation obtained is as follows:

$$
\dot{Y}=5.646+0.534 \mathrm{X} 1+0.193 \mathrm{X} 2+0.032 \mathrm{X} 3+
$$
$0.140 \mathrm{X} 4+0.241 \mathrm{X} 5$.

Effect of Tangible Variables on Satisfaction of General Outpatient Patients at Royal Prima Hospital Medan

The results of statistical test analysis using multiple linear regression tests on the Tangible Variables on the satisfaction of general patients outpatient Royal Prima Medan Hospital significant value $\mathrm{p}=0.000<0.05$ and the value of $\mathrm{B}=0.534$. This shows that there is a positive and significant influence between physical evidence on the level of patient satisfaction. The results of the analysis can explain that patient satisfaction increases with the availability of the Royal Prima Hospital building is nice and attractive, the room is clean and comfortable, complete facilities, neat and comfortable examination room, and doctors and medical staff Outpatient Royal Prima Hospital look neat. The research results of Rahmadhani concluded that the variables of facilities and infrastructure for health services (medical facilities, medical and non-medical support) had a positive and significant effect on the trust of 
patients in RSUD dr.H. Yuliddin Away, Tapaktuan. ${ }^{-}$The results of Wusko's research on the Effect of Service Quality on Service User Satisfaction in the Bangil District General Hospital of Pasuruan Regency, stated that there was a significant influence between the service quality variables in the form of physical evidence on the variable service satisfaction of patients (patients) at the Bangil Hospital in Pasuruan Regency..$^{10}$

This is in accordance with the opinion of Gde Muninjaya..$^{-11}$ One of the factors that can affect users of health services is the physical appearance (neatness) of officers, the condition of cleanliness and comfort of the room (tangible). In other words, patient satisfaction will increase if the Royal Prima RSU tangible is increased. With the increase in the satisfaction of general outpatients, Royal Prima Medan Hospital will support the Vision and Mission of Royal Prima Hospital.

\section{Effect of Reliability Variables on Satisfaction of General Outpatient Patients at Royal Prima Hospital Medan}

The results of statistical test analysis using multiple linear regression tests on Reliability Variables to the satisfaction of general outpatient patients Royal Prima Medan Hospital significant value $\mathrm{p}=0.028<0.05$ and $\mathrm{B}$ value $=0.193$. This shows that there is a positive and significant influence between the reliability of the satisfaction of general outpatient patients at Royal Prima Hospital in Medan. The results of the analysis can explain that patient satisfaction increases with the availability of doctors and medical staff in outpatient Royal Prima Hospital on time, skilled, have knowledge of treatment measures, registration procedures for outpatients of Royal Prima Hospital are not complicated. States that the service quality dimension of reliability is the ability to provide reliable and accurate services. This is in line with the Health Service Quality dimension of reliability proposed by Parasuraman, Berry, et al in Astuti that service accuracy and smooth service are often perceived as the most important service. ${ }^{12}$ In other words, patient satisfaction will increase if the reliability of Royal Prima Hospital increases according to the vision and mission of Royal Prima Hospital. $\underline{13}$

Effect of Responsiveness Variables on Satisfaction of General Outpatient Patients at Royal Prima Hospital Medan

The results of statistical test analysis using multiple linear regression tests on the responsiveness variable on the satisfaction of general outpatient patients at Royal Prima
Medan Hospital significant value $\mathrm{p}=0.539>00.5$ and the coefficient value $B=0.032$. The results of the analysis show that there is a positive but not significant effect on the satisfaction of general patients outpatient at Royal Prima Medan Hospital. Concern for health workers when patients are seeking help for health problems that naturally affect patient satisfaction in the Outpatient Room at Royal Prima Hospital Medan. But in this study responsiveness did not prove significant to patient satisfaction. According to Nurmawati said that responsiveness is the ability of officers to provide responsive and immediate services, easily accessible, not long to wait, willing to hear the complaints of patients.

Effect of Variable Assurance on Satisfaction of General Outpatient Patients at Royal Prima Hospital Medan

The results of the statistical test analysis using multiple linear regression tests on assurance variables on the satisfaction of general outpatient patients at Royal Prima Medan Hospital significant value $\mathrm{p}=0.031$ and $\mathrm{B}=$ 0.140 . This shows that there is a positive and significant influence between assurance and certainty on the satisfaction of general outpatient patients at Royal Prima Hospital in Medan. The results of the analysis can explain that patient satisfaction increases with the availability of doctors and medical staff Outpatient Royal Prima Hospital is friendly in serving patients, doctors and medical staff have extensive communication and knowledge, Royal Prima Medan Hospital guarantees the safety and comfort of patients, ensures the availability of services needed.

This is in accordance with the results of Suparttiningsih if the trustworthy nature of employees increases, patient satisfaction at the Sarila Husada hospital in outpatients will also increase..$^{14}$ Quality of Health Services Dimensions of assurance and certainty proposed by Parasuraman, Berry, et al in Astuti that the existence of guarantees including knowledge, skills, politeness, the ability of officers in communication and trustworthy characteristics possessed by officers can influence patient judgment. In other words, patient satisfaction will increase if the guarantee and certainty of the Royal Prima Hospital RSU are improved. Improving the Quality of Health Services on the dimensions of guarantee and certainty will affect patient satisfaction so that it will support the Vision and Mission of Royal Prima Hospital. 


\section{Effect of Empathy Variables on Satisfaction of General Outpatient Patients at Royal Prima Hospital Medan}

The results of statistical test analysis using multiple linear regression tests on the Empathy Variables on the satisfaction of general outpatient patients at Royal Prima Medan Hospital significant value $\mathrm{p}=0.003<0.05$ and $\mathrm{B}$ value $=0.241$. This shows a positive and significant influence between satisfaction with general patients outpatient at Royal Prima Hospital in Medan. According to Hadiyatma et al., 2017 poor empathy has three times greater capacity to increase patient dissatisfaction. Empathy is a concern given by health professionals mentioned above which is good enough, but it is expected to increase more sympathy for individuals towards the very diverse needs of

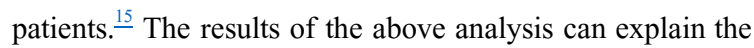
increased patient satisfaction with testing doctors and medical staff Outpatient Royal Hospital Prima attentive, can meet the needs of patients, can communicate well with patients, willingness to consult with patients, doctors and medical staff do not show social status, and recognize or remember patients. This is in accordance with Helmawati's research if the empathy dimension increases then patient satisfaction will increase. ${ }^{16}$

Based on the results of the analysis given to patients who received health services provided by the Royal Prima Hospital Medan. The results of this study contradict the research conducted by Okky Erviana, et al, namely service quality and a significant positive belief in patient satisfaction. ${ }^{17}$ Service quality can be realized through meeting the needs and desires of consumers, as well as the accuracy of delivery in balancing or exceeding consumer expectations. $\stackrel{18}{ }$

Research conducted by Wira, et al, in his research at Wangaya City Hospital Denpasar showed that there was an influence on service quality consisting of reliability, responsiveness, assurance, empathy had a significant influence on patient satisfaction..$^{\frac{19}{9}}$ The confirmed by the research of Radito in Wijani the determinants of patient satisfaction in Muhamaddiyah hospital is the form of skills of medical personnel, responsiveness of health workers in meeting patient needs, empathy, respect, and hospitality in serving patients. $\stackrel{20}{-}$

\section{CONCLUSION}

Based on the results of the research and analysis that have been previously published, conclusions can be drawn as follows: Has Tangible positive and significant influence on General Patient Satisfaction at Royal Prima Medan Hospital. Royal Prima Hospital is nice and attractive, the room is clean and comfortable, the facilities are complete, the examination room is neat and comfortable, and the outpatient doctors and medical staff of Royal Prima Hospital look neat. Positive and significant reliability on the satisfaction of general outpatient patients at Royal Prima Hospital Medan. This explains that patient satisfaction increases with the availability of doctors and medical staff in outpatient Royal Prima Hospital on time, consultation, knowledge of treatment, registration procedures for Outpatient patients at Royal Prima Hospital are not complicated. Looks positive but not significant Response to satisfaction of general patients Outpatient Royal Prima Hospital in Medan.

This explains that patient satisfaction increases with the concern of health workers to compile patients who are seeking help for their natural health problems. But in this study responsiveness did not prove significant to patient satisfaction. Giving a positive and significant influence on general outpatient patient guarantees in the Royal Prima Hospital Medan. RSU Royal Prima serves patients, doctors and outpatient medical staff RSU Royal Prima serves patients, doctors and medical staff, RSU Royal Prima Medan provides patient safety and comfort services, ensuring the necessary care. Giving a positive and significant influence on Empathy towards general patient satisfaction. Royal Prima Hospital Street in Medan. This explains that patient satisfaction increases with the availability of doctors and medical staff Outpatient Royal Hospital Prima attentive, can meet the needs of patients, can communicate well with patients, cannot see the social status, and is able to recognize or remember patients. Based on the results of multiple linear regression analysis, the Independent variable of the Quality of Health Services (X) which is the most dominant influence on the Patient Satisfaction Dependent (Y) variable is the Tangible variable.

\section{REFERENCE}

1. KeMenKes RI. Profil kesehatan Indonesia tahun 2015. Jkt Kementeri Kesehat Repub Indones. 2016;

2. Pohan IS. Jaminan mutu layanan kesehatan: dasardasar pengertian dan penerapan. Jkt Egc. 2007;

3. Alamsyah D. Manajemen Pelayanan Kesehatan. Yogyakarta: Nuha Medika; 2012. (2).

4. M. Fais S. Organisasi dan Manajemen Pelayanan Kesehatan: Teori dan Aplikasinya dalam Pelayanan Puskesmas dan Rumah Sakit [Internet]. Salemba Medika; 2014. Tersedia pada: http://repositori.uinalauddin.ac.id/13200/ 
5. Zeithaml A, Valerie A, Parasuraman, Leonard LB. 'Delivering Quality Service - Balancing Customer Perceptions and Expectations' [Internet]. New York: The Free Press; 1990. Tersedia pada: https://www.worldcat.org/title/delivering-qualityservice-balancing-customer-perceptions-andexpectations/oclc/20357056

6. Sangadji EM, Sopiah. Perilaku Konsumen: Pendekatan Praktis Disertai: Himpunan Jurnal Penelitian. Yogyakarta: Penerbit Andi; 2013.

7. Sugiyono. Metode Penelitian Pendidikan Pendekatan Kuantitatif, Kualitatif dan R\&D. Bandung: Alfabeta; 2014.

8. Pohan IS. Jaminan Mutu Layanan Kesehatan. Jakarta: EGG; 2013.

9. Rahmadhani M. Pengaruh Sarana dan Prasarana Serta Kontak Personal terhadap Kepercayaan Pasien di Rumah Sakit Umum Daerah dr. H. Yuliddin Away Tapaktuan [Internet]. [Sumatera Utara]: Universitas Sumatera Utara; 2013. Tersedia pada: http://repository.usu.ac.id/handle/123456789/35580

10. Any Urwatul Wusko. Pengaruh Kualitas Pelayanan Terhadap Kepuasan Pengguna Jasa Pada Rumah Sakit Umum Daerah Bangil Kabupaten Pasuruan. Sketsa Bisnis [Internet]. 7 Agustus 2015 [dikutip 16 Agustus 2019];1(1). Tersedia pada: https://jurnal.yudharta.ac.id/v2/index.php/SKETSABI SNIS/article/view/23

11. Muninjaya AAG. Manajemen Kesehatan. Jakarta: EGC Jakarta; 2010. (3).

12. A., Zeithaml Parasuraman, Valarie, Berry L. Kualitas Pelayanan. Jakarta: Penerbit FK UI; 2006.
13. Purwoastuti E, Elisabeth SW. Mutu Pelayanan Kesehatan dan Kebidanan. Jakarta: Pustaka Baru Press;

14. Supartiningsih S. Kualitas Pelayanan Kepuasan Pasien Rumah Sakit: Kasus Pada Pasien Rawat Jalan. JMMR J Medicoeticolegal Dan Manaj Rumah Sakit. 2017;6(1):9-15

15. Widi Hastuti K, Ahid Mudayana A, Putri Nurdila A. Hubungan Mutu Pelayanan dengan Kepuasan Pasien Peserta BPJS di Rumah Sakit Umum Daerah Yogyakarta. 2017;11(2).

16. Helmawati T, Handayani SD. Pengaruh kualitas layanan terhadap minat kunjungan ulang yang dimediasi oleh kepuasan pasien di klinik Rumah Zakat Yogyakarta. JMMR J Medicoeticolegal Dan Manaj Rumah Sakit. 2014;3(1).

17. Erviana O. Pengaruh Kualitas Pelayanan Dan Kepercayaan Terhadap Kepuasan Pasien Rawat Inap Di Rsud Dr. Soewondo Kendal [Internet]. [Semarang]: Universitas Negeri Semarang; 2013. Tersedia pada: https://lib.unnes.ac.id/18365/

18. Tjiptono F, Chandra. Pemasaran Strategi. Yogyakarta: Penerbit Andi; 2012.

19. Wira DAI. Hubungan antara persepsi mutu pelayanan dokter dengan kepuasan pasien rawat inap kelas III di RSUD Wangaya [Internet]. [Denpasar]: Universitas Udayana; 2014. Tersedia pada: https://docplayer.info/443707-Tesis-hubunganantara-persepsi-mutu-pelayanan-asuhan-keperawatandengan-kepuasan-pasien-rawat-inap-kelas-iii-di-rsudwangaya-kota-denpasar.html

20. Radito T. Analisis Pengaruh Kualitas Pelayanan Dan Fasilitas Kesehatan Terhadap Kepuasan Pasien Puskesmas. J Ilmu Manaj. 2014;11(2):1-25. 